\title{
LETTERS
}

J. Raptor Res. 50(4):422-424

(C) 2016 The Raptor Research Foundation, Inc.

\section{A Case of Predation of a Eurasian Eagle-Owl by a Bonelli's Eagle}

\author{
PASCUAL López-López ${ }^{1}$ \\ "Cavanilles" Institute of Biodiversity and Evolutionary Biology, Terrestrial Vertebrates Group, University of Valencia, \\ C/ Catedrático José Beltrán 2, E-46980, Paterna, Valencia, Spain \\ Clara García-Ripollés, José Giménez, and Vicente Urios \\ Vertebrates Zoology Research Group, CIBIO Research Institute, University of Alicante, Apdo. 99, E-03080 Alicante, Spain
}

Key WorDS: Bonelli's Eagle; Aquila fasciata; Eurasian EagleOwl; Bubo bubo; interspecific competition; intraguild predation; superpredation.

Superpredation, defined as an interaction in which a predator kills and eats another predator, has been widely studied previously (Lourenço et al. 2011b, 2014) and is a widespread phenomenon in raptor assemblages (Sergio and Hiraldo 2008). A particular case of superpredation is intraguild predation, in which a species preys on another species of the same guild that could be a potential competitor (Polis et al. 1989). Although sometimes overlooked in dietary analyses, superpredation can be an important mechanism regulating population dynamics that leads to behavioral responses among different members of the community (Lourenço et al. 2014).

It is well known that the Eurasian Eagle-Owl (Bubo bubo) is one of the greatest top predators of the Palearctic region (Cramp and Simmons 1980, Ferguson-Lees and Christie 2001). However, the opposite situation, in which eagle-owls are predated by other raptors, is extremely uncommon (Mikkola 1976, Lourenço et al. 2011b). The Bonelli's Eagle (Aquila fasciata) and Eurasian Eagle-Owl (Bubo bubo) are long-lived territorial species that coexist in sympatry in southwestern Europe, and are considered top avian predators in human-dominated Mediterranean ecosystems (Cramp and Simmons 1980, Ferguson-Lees and Christie 2001). Although these species show some degree of dietary and niche overlap (e.g., competition for prey and nest sites), eagles and owls reduce competition via temporal niche partitioning (Lourenço et al. 2011b): Bonelli's Eagles concentrate their activities during the daytime, whereas owls are crepuscular. On very rare occasions, Eurasian Eagle-Owls prey upon Bonelli's Eagles, particularly nestlings (Bayle 1987, Real and Mañosa 1990).

According to previous work, three raptor species have been recorded killing Eurasian Eagle-Owls: Golden Eagles (Aquila chrysaetos) in Sweden, Finland, and Mongolia

\footnotetext{
${ }^{1}$ Email address: Pascual.Lopez@uv.es
}

(Mikkola 1976, Ellis et al. 2000); White-tailed Eagle (Haliaeetus albicilla) in Sweden (Mikkola 1976); and Steppe Eagle (Aquila nipalensis) in Russia (Vazhov et al. 2013). However, there are no published detailed observations of a case of predation of a Eurasian Eagle-Owl by a Bonelli's Eagle. To the best of our knowledge, there is only one reported case of consumption of a Eurasian Eagle-Owl by a Bonelli's Eagle in the literature (Martínez et al. 1994), but no details were given that would allow determination of whether it was a case of predation or simply opportunistic scavenging. Here, we report a case of predation of a Eurasian Eagle-Owl by a Bonelli's Eagle, which we documented during a remote tracking research project conducted in Sierra de Espadán Natural Park, Castellón, Spain $\left(39^{\circ} 52.0^{\prime} \mathrm{N}, 0^{\circ} 17.5^{\prime} \mathrm{W}\right)$.

During 2015, we trapped and equipped a territorial pair of Bonelli's Eagles with solar GSM-GPS-ACC loggers (48g; e-obs GmbH, Gruenwald, Germany) using Teflon backpack-style harnesses. We programmed the tags to record GPS locations every 5 min from $1 \mathrm{hr}$ before sunrise until 1 hr after sunset. The pair consisted of an adult male $(>4 \mathrm{yr}$ old, mass $=2000 \mathrm{~g}$ ) that we trapped on 10 June 2015 and a subadult female $(2 \mathrm{yr}$ old, mass $=2900 \mathrm{~g}$ ) trapped on 6 November 2015. We determined these birds were paired based on observations of territorial and pair-bond behavior (e.g., often observed flying together; P. López- López, C. García-Ripollés, J. Giménez, and V. Urios unpubl. data).

The predation event occurred on 28 November 2015, when the subadult female eagle roosted at $1755 \mathrm{H}$ in the middle part of a hillside, very close to a few isolated pine trees (Pinus halepensis). She remained in the same place until $1135 \mathrm{H}$ the next day (29 November 2015) and came back at $1710 \mathrm{H}$ in that evening. She remained overnight and did not move until $1315 \mathrm{H}$ the next day (30 November 2015). On 1 December 2015, the female returned again to the same place from $1000-1045 \mathrm{H}$, and from $1250-1325 \mathrm{H}$ on 2 December 2015.

The male eagle went with the female on 28 November 2015 at $1755 \mathrm{H}$. He remained close to the female at the predation location until 29 November 2015 at $0750 \mathrm{H}$. 
Then, he moved to a perch located in the upper part of the hill and his last visit to the predation location took place from 1125-1135 H on 29 November 2015. Afterwards, the male did not revisit the predation location, but made short visits to the vicinity $(<250 \mathrm{~m})$ on 29 November 2015 at 1630 $\mathrm{H}$, on 30 November 2015 from $1555-1600 \mathrm{H}$, on 1 December from 0925-0945 H, and finally, on 2 December 2015 from $1125-1135 \mathrm{H}$.

Because of the unusual recording by GPS telemetry, we visited the cluster of GPS locations on 1 December 2015 from 1030-1300 $\mathrm{H}$. We found the partially consumed carcass of a Eurasian Eagle-Owl. Importantly, the owl remains were still fresh (i.e., blood was not completely coagulated), ruling out the possibility that eagles were scavenging on the carcass. We took several pictures and collected tissue samples and feathers. According to molecular sexing (Griffiths et al. 1998) and plumage characteristics (Martínez et al. 2002), the eagle-owl was a thirdcalendar-year male. Interestingly, the event occurred just at dusk (the sun set at $1737 \mathrm{H}$ on 28 November 2015; Spanish National Geographical Institute, http://www.fomento.gob. es/), during the period of the year when Eurasian EagleOwl vocal activity is highest, associated with territorial and pre-breeding behaviors. Furthermore, there was spatial overlap between the territory of the Bonelli's Eagle pair and an eagle-owl's territory in this area (P. López- López, C. García-Ripollés, J. Giménez, and V. Urios unpubl. data).

Four different hypotheses could account for this unusual superpredation behavior between the Bonelli's Eagle and the eagle-owl: (1) food-stress hypothesis (Serrano 2000, Lourenço et al. 2011b), which postulates that the top predator searches for alternative prey species in situations of food scarcity; (2) the competitor-removal hypothesis (Serrano 2000), which implies that Bonelli's Eagles perceive eagle-owls as potential competitors and deliberately eliminate them; (3) the predator-removal hypothesis (Lourenço et al. 2011a, 2014), by which Bonelli's Eagles would kill eagle-owls to avoid predation by the owls; and, (4) the "opportunistic diet hypothesis" (Polis et al. 1989), which suggests that the Bonelli's Eagle could have preyed upon the eagle-owl by chance as a consequence of an injury or illness of the latter. Although some of these hypotheses are not mutually exclusive, in light of our field observations and experience with both species in the study area, we would favor the first hypothesis as food availability is low in our study area (P. López- López, C. García-Ripollés, J. Giménez, and V. Urios unpubl. data). The second and third hypotheses could also account for this behavior, especially considering previous events of nestling Bonelli's Eagles being killed by eagle-owls (Real and Mañosa 1990). Notwithstanding, if the "predatorremoval hypothesis" were true, the frequency of lethal interactions among both species would be probably much higher and thus previously reported in the literature. Unfortunately, we cannot rule out the fourth hypothesis, as the eagle-owl was partially consumed and hence we were unable to determine information about its body condition.
We thank J. Real, J.E. Martínez, J.A. Sánchez-Zapata, and M. Moleón for providing valuable bibliographical references. J. Ferré and G. Navarrete (Dept. Genetics, University of Valencia) sexed the eagle-owl. I. Zuberogoitia helped with age estimation of the owl. Red Eléctrica de España S.A.U. provided financial support for this project. Special thanks to J. Jiménez and Conselleria d'Agricultura, Medi Ambient, Canvi Climàtic i Desenvolupament Rural of the Generalitat Valenciana for their help with this project. S. Lewis and J.E. Martínez provided valuable comments to improve this letter. PLL is supported by a Juan de la Cierva-incorporación postdoctoral grant of the Spanish Ministry of Science and Innovation (IJCI-2014-19190). Eagle trapping and satellite tagging was conducted under permit number "123/2016-VS (FAU 016_012)" licensed by the regional administration "Generalitat Valenciana."

\section{Literature Cited}

BAYLe, P. 1987. Découverte des restes d'un aigle de Bonelli Hieraaetus fasciatus juvenile dans une aire de Hibou Grand-duc Bubo bubo en Provence. Faune de Provence 8:49-53.

Cramp, S. And K.E.L. Simmons [Eds.]. 1980. The birds of the western Palearctic. Vols. 1 and 2. Oxford University Press, Oxford, U.K.

Ellis, D.H., P. Tsengeg, P. Whitlock, ANd M.H. Ellis. 2000. Predators as prey at a Golden Eagle Aquila chrysaetos eyrie in Mongolia. Ibis 142:139-142.

Ferguson-Lees, J. And D.A. Christie. 2001. Raptors of the world. Houghton Mifflin Company, New York, NYU.S.A.

Griffiths, R., M.C. Double, K. OrR, AND R.J.G. DAwson. 1998. A DNA test to sex most birds. Molecular Ecology 7:1071-1075.

Lourenco, R., V. Penteriani, M.M. Delgado, M. MarchiBARTOLOZZI, AND J.E. RABAÇA. 2011a. Kill before being killed: an experimental approach supports the predator removal hypothesis as a determinant of intraguild predation in top predators. Behavioral Ecology and Sociobiology 65:1709-1714.

_ , V. Penteriani, J.E. RabaÇA, And E. KorpimÄKi. 2014. Lethal interactions among vertebrate top predators: a review of concepts, assumptions and terminology. Biological Reviews 89:270-283.

- S.M. SANTOS, J.E. RabaÇA, AND V. PENTERIANi. 2011 b. Superpredation patterns in four large European raptors. Population Ecology 53:175-185.

Martínez, J.A., I. Zuberogoitia, and R. Alonso. 2002. Nocturnal raptors: guide to age and sex identification in the Iberian Strigiformes. Monticola Ed., Madrid, Spain.

Martínez, J.E., M.A. SÁnchez, D. Carmona, And J.A. SÁnCHEZ-ZAPATA. 1994. Régime alimentaire de l'aigle de Bonelli Hieraaetus fasciatus durant la période de l'élevage des jeunes (Murcia, Espagne). Alauda 62:53-58.

MikкоLA, H. 1976. Owls killing and killed by other owls and raptors in Europe. British Birds 69:144-154.

Polis, G.A., C.A. Myers, AND R.D. Holt. 1989. The ecology and evolution of intraguild predation: potential com- 
petitors that eat each other. Annual Review of Ecology, Evolution, and Systematics 20:297-330.

ReAL, J. AND S. Mañosa. 1990. Eagle owl (Bubo bubo) predation on juvenile Bonelli's Eagles (Hieraaetus fasciatus). Journal of Raptor Research 24:69-71.

SERGio, F. AND F. HiRAldo. 2008. Intraguild predation in raptor assemblages: a review. Ibis 150:132-145.

SERRANO, D. 2000. Relationship between raptors and rabbits in the diet of eagle owls in southwestern Europe: competition removal or food stress? Journal of Raptor Research 34:305-310.

Vazhov, S.V., R.F. Bachtin, A.N. Barashkova, and I.E. SMELANSKY. 2013. On the study of the Steppe Eagle in the Altai Kray, Russia. Raptors Conservation 27:162-171.

Received 9 March 2016; accepted 17 May 2016

Associate Editor: Stephen B. Lewis

J. Raptor Res. 50(4):424-425

(C) 2016 The Raptor Research Foundation, Inc.

\title{
Turkey Vulture Scavenging Prey at a Broad-winged Hawk Nest
}

\author{
Rebecca A. McCabe, ${ }^{1}$ Cassie L. Baun, and Terry L. Master \\ Department of Biological Sciences, East Stroudsburg University, East Stroudsburg, PA 18301 U.S.A. \\ LAURIE J. GOODRICH AND KeITH L. BILDSTEIN \\ Acopian Center for Conservation Learning, Hawk Mountain Sanctuary, 410 Summer Valley Road, \\ Orwigsburg, PA 17961 U.S.A.
}

KeY WoRDS: Turkey Vulture, Cathartes aura; Broad-winged Hawk; Buteo platypterus; breeding; diet; hawk; scavenging.

Turkey Vultures (Cathartes aura) use a keen sense of smell and eyesight to locate potential prey even within dense forests (Chapman 1938, Stager 1964, Houston 1986). As opportunistic feeders, vultures vary their diets, depending on local and regional availability of large and small mammals and non-mammals, either wild or domestic (Hiraldo et al. 1991). Generally, Turkey Vultures prefer to feed on the ground on relatively fresh carrion (Owre and Northington 1961); they also feed in other unusual ways, such as wading in shallow water to fish and feed on carcasses (Jackson et al. 1978), or sometimes landing on and feeding on floating carcasses (e.g., American alligator [Alligator mississippiensis] and manatee [Trichechus spp.]; Bendire 1982, Morant and Winter 1984). While conducting behavioral observations on nesting Broad-winged Hawks (Buteo platypterus) in Delaware State Forest in eastern Pennsylvania, we observed a Turkey Vulture scavenging on prey remains within the nest of a Broad-winged Hawk.

On 13 July 2015, CLB arrived at $0700 \mathrm{H} \mathrm{EDT}$ at one of the Broad-winged Hawk nest study sites in the Delaware State Forest, Pike County, PA $\left(41^{\circ} 15.87^{\prime} \mathrm{N}, 75^{\circ} 01.21^{\prime} \mathrm{W}\right)$. Habitat around the nest, which was in a 19.6-m tall white oak tree (Quercus alba), was mixed-deciduous forest with a nearby stream and pond. We observed hawk nesting activity with a 20-60× zoom KOWA TSN-821 spotting scope from a blind $60 \mathrm{~m}$ from the nest tree. We had observed this nest,

\footnotetext{
${ }^{1}$ Email address: rebeccamccabe2@gmail.com
}

which originally contained two nestlings that hatched 1618 June 2015, twice weekly since 20 May 2015. On 13 July, only one Broad-winged Hawk nestling was at the nest, the other having disappeared sometime between 10 and 13 July. An adult hawk visited the nest three times during the morning to deliver prey: an eastern chipmunk (Tamias striatus) at $0808 \mathrm{H}$, an unidentified prey item at $0926 \mathrm{H}$, and a small passerine at $1057 \mathrm{H}$. The adult fed the unidentified prey to the single young for $11 \mathrm{~min}$, starting at $0926 \mathrm{H}$, but left the first and third prey items in the nest for the nestling. The nestling fed on these prey items, intermittently, for 35 min after the delivery of the third item.

At 1208 H, CLB saw a Turkey Vulture flying above the canopy. In less than $1 \mathrm{~min}$, it perched on an adjacent tree, about $3 \mathrm{~m}$ above the nest, and hissed several times. At 1209 $\mathrm{H}$, the vulture moved from the adjacent tree onto a branch in the nest tree, approximately $1 \mathrm{~m}$ above the nest. At 1210 $\mathrm{H}$ the Turkey Vulture took a step backward and down toward the nest. It continued to move down the branch, backing into the nest with wings partially extended. At the same time, the nestling walked about $0.5 \mathrm{~m}$ onto a branch in the opposite direction out of the nest. The Turkey Vulture started to consume the remains of both the eastern chipmunk and passerine the adult had delivered to the nest. The nestling continued to move away from the vulture along the branch at $1212 \mathrm{H}$, stopping approximately 3-5 m from the nest. The Turkey Vulture continued to consume prey remains in the nest for the next $11 \mathrm{~min}$.

At $1223 \mathrm{H}$, an adult Broad-winged Hawk silently approached the nest tree from the east and flew at the Turkey Vulture. The Turkey Vulture took flight immedi- 